\title{
EFFECT OF DRYING METHODS ON CHEMICAL COMPOSITION OF MORINGA LEAVES POWDER
}

\author{
Salah Y. Mansour ${ }^{* 1}$, Seham F. Abd El-Moity ${ }^{1}$, Gehan A. El-Shourbagy ${ }^{2}$ and H.A. Siliha ${ }^{2}$ \\ 1. Pl. Prod. Dept., Des. Res. Cent., Egypt \\ 2. Food Sci. Dept., Fac. Agric. Zagazig Univ., Egypt
}

\begin{abstract}
Moringa leaves contain large amount of several important nutrients which are essential to the human body. The present investigation efforts have been made to prepare powder from (Moringa oleifera L.) leaves by different drying methods, including shadow drying, and oven drying at different temperatures $\left(50^{\circ} \mathrm{C}, 60^{\circ} \mathrm{C}\right.$ and $\left.70^{\circ} \mathrm{C}\right)$. Results indicated that shadow dried sample was better than oven dried samples due its high nutrients content. Moisture, protein, fat, fiber, ash and total carbohydrate contents of moringa powder were found in the range of $4.80-6.77 \%, 21.52$ to $22.90 \%$, $7.94-9.11 \%$, 9.36-11.21\%, 7.71-8.13\% and 53.09- 60.12\%, respectively. Sixteen amino acids were identified in moringa leaves powder. Lysin, leucine and phenylalanine were the most abundant essential amino acids in all studied samples. Moringa leaves powder contained 17 fatty acids. The highest saturated fatty acid was palmitic acid $\left(\mathrm{C}_{16: 0}\right)$ of dried moringa leaves dried at $50^{\circ} \mathrm{C}(10.77 \mathrm{~g} / 100 \mathrm{~g}$ fat $)$ while the major unsaturated fatty acid was $\alpha$-Linolenic $\left(\mathrm{C}_{18: 3}\right)$ of dried moringa leaves dried at $60^{\circ} \mathrm{C}(52.46$ $\mathrm{g} / 100 \mathrm{~g}$ fat). Vitamins $\mathrm{A}, \mathrm{E}$ and $\mathrm{C}$ were present in different concentrations, where the highest values were found in fresh moringa leaves followed by leaves dried in shadow while those of lower values were found in oven dried sample. Results also illustrated that the moringa leaves powder is rich source of natural antioxidants. The highest content of the identificated sugars in moringa leaves powder (shadow drying) was stachyose (1009.75 mg/100g). Glucuronic acid was found in moderate concentration (876.59 mg/100g). Sucrose and raffinose were also detected (608.68 mg/100g, 607.89 $\mathrm{mg} / 100 \mathrm{~g})$, respectively in moringa leaves powder. The study revealed that dried leaf powder of moringa can serve as an excellent source of nutrientional value and it was concluded that shadow drying method was the best method for drying moringa leaves.
\end{abstract}

Key words: Moringa oleifera leaves, shadow drying; oven drying, nutrients, chemical composition, antioxidants.

\section{INTRODUCTION}

Moringa (Moringa oleifera L.) is considered one of the most useful trees, in the world. As almost every part of the moringa tree can be used for food, medication and industrial purposes (Khalafalla et al., 2010). In many tropical and subtropical countries, various parts of moringa (leaves, fruits, immature pods, and flowers) are incorporated in the traditional food for humans (Siddhuraju and Becker, 2003; Anhwange et al., 2004). Moringa commonly known as drumstick, horse radish, shobhanjana, murungai, soanjna, shajna, sainjna is often known as "mother's best friend". Due to its high content of bioactive compounds, moringa leaves have been used in wide applications of food products. (Siddhuraju and Becker, 2003; Anwar et al., 2005; Fahey, 2005; Price, 2007; Singh and Prasad, 2013). Moringa leaves have been reported to be a rich source of $\beta$-carotene, protein, vitamin $\mathrm{C}$, calcium and potassium and act as a good source of natural antioxidants, thus prolonging the shelf-life of fat containing foods

\footnotetext{
*Corresponding author: Tel. : +201222765314

E-mail address: salahyehia66@gmail.com
} 
due to the presence of various types of antioxidant compounds such as ascorbic acid, flavonoids, phenolics and carotinoids (Siddhuraju and Becker, 2003; Anwar et al., 2005; Anwar et al., 2007 ; Price, 2007). Total antioxidant activity of moringa pods was $133.78 \%$ and in moringa leaves was $168.34 \%$ (El-Masry et al., 2013)

Moringa leaves are rich source of flavonols such as kaempferol and 3'-OMe quercetin. A flavone, acacetin and a glycoflavone 4-OMe Vitexin were also identified. Phenolic acids identified in moringa leaves included melilotic acid, p-coumaric acid, and vanillic acid (Nambiar and Daniel, 2005).

Daily intake of 25 grams of moringa leaves powder was found to provide child with $42 \%$ protein, $125 \%$ calcium, $61 \%$ potassium, $41 \%$ magnesium, $71 \%$ iron, $272 \%$ vitamin $\mathrm{A}$ and $22 \%$ vitamin $\mathrm{C}$ of the recommended allowances (Folkard and Sutherland, 1996).

Fresh moringa leaves were found to contain high amount of amino acids, especially essential amino acids such as, methionine, valine, phenylalanine, leucine, lysine and tryptophan, accounting for 2.12, 6.47, 6.38, 10.12, 6.73 and $2.17 \mathrm{~g} / 100 \mathrm{~g}$ protein, respectively (El-Masry et al., 2013).

Moringa leaves have been used to combat malnutrition, especially among infants and nursing mothers and hasten uterine contraction during child birth in pregnant women. It's antihypertensive, diuretic, antispasmodic, antiulcer, and anticancer and cholesterol lowering activities have been reported (Caceres et al., 1992; Dangi et al., 2002).

Leaves of moringa are traditionally used as purgatives and in the treatment of headaches, hemorrhoids, fevers, inflammation of noise and throat, bronchitis, eye and ear infections, and to combat vitamin C deficiency (Mukunzi et al., 2011). Drying of plant leaves increases its shelf life. For drying fruits and vegetables different methods are used such as direct sun drying, shadow, cabinet drying, oven drying, and freeze drying (Satwase et al., 2013) .

Liman et al. (2014) examined the effect of three different drying techniques (sun drying, oven drying at $150^{\circ} \mathrm{C}$ for $4 \mathrm{hr}$., and drying with electrical moisture analyzer stabilized at $70^{\circ} \mathrm{C}$ for 1 day) on the mineral composition $(\mathrm{Ca}, \mathrm{K}$, $\mathrm{Mg}, \mathrm{Na}$, and $\mathrm{P}$ ) of moringa leaves . They could not obtain definite conclusion as which method is the best to be used. Nutrient, had been retained in moringa seeds in cabinet-tray drying method (in terms of protein and fat) compared to oven drying, sun drying and shadow drying (Aremu and Akintola, 2014).

Olabode et al. (2015) examined the effect of drying temperature 60,70 and $80^{\circ} \mathrm{C}$ on the nutrients of moringa leaves. Moisture, protein, fat and crude fiber contents of moringa leaves were decreased while ash and tannin contents increased as temperature increased. Temperature of drying had varing effects on the components of leaves.

Satwase et al. (2013) studied the effect of sun drying, shadow drying, cabinet drying, and oven drying at $60^{\circ} \mathrm{C}$. Cabinet dried samples were the best samples. It had highest nutrient retention followed by shadow, sun drying and oven dried samples. Cabinet tray drying method was observed as suitable dehydration process of drumstick leaves.

The aim of the present study was to examine the effect of two drying techniques, namely, shadow drying at ambient temperature as well as oven drying at $\left(50,60\right.$ and $\left.70^{\circ} \mathrm{C}\right)$ on chemical composition of moringa leaves.

\section{MATERIALS AND METHODS}

\section{Materials}

Moringa leaves were obtained from of El-Shikh Zwide Research Station in North Sinai, Desert Research Centre, Ministry of Agriculture at two successive seasons 2014 and 2015.

\section{Methods}

\section{Preparation of Samples}

Fresh leaves were collected from moringa tree were cleaned by removing stems and other unwanted parts. The leaves were washed with warm water $30^{\circ} \mathrm{C} \pm 4$ to remove dirt particles. The excess water was allowed to drain out from leaves then moringa leaves were put on a piece of cotton cloth to absorb up the remaining of the tap water at room temperature. 


\section{Drying Techniques}

The fresh leaves were dried in shadow and hot air using electric oven as follow:

\section{Shadow Drying}

The leaves were spread on filter papers and kept at room temperature for seven days. The leaves turned over once per day. Care was taken to observe that there was no fungal growth on the leaves (Satwase et al., 2013).

\section{Oven Drying}

Moringa leaves were spread on drying trays $(38 \times 27 \mathrm{~cm})$ and dried in a laboratory drying oven (Heraeus instruments - Germany) equipped with a ventilating fan. Drying was carried out at three different temperatures $\left(50,60\right.$ and $70^{\circ} \mathrm{C}$ for $48 \mathrm{hr}$.) as reported by Satwase et al. (2013)

\section{Grinding Leaves}

The dried moringa leaves were ground in a mill (company IKA-Germany) containing sieves with narrow holes to get powder $\leq$ $0.5 \mathrm{~mm}$. The moringa leaves powder were collected and stored in black plastic pags at room temperature.

\section{Chemical Analyses}

Moisture, protein, fat, ash and crude fiber contents were determined according to AOAC (2005). Total carbohydrate content was calculated by difference as follows: $100-(\%$ moisture + fat + protein + ash).

\section{Determination of Amino acids}

Amino acids were separated on INGOS amino acid analyzer (Model: AAA400).

\section{Preparation of Hydrolyzed Amino Acids}

Preparation of hydrolyzed amino acids was according to the method of Csomos and SimonSarkadi (2002), as follow:

1. The dried and defatted grinding sample $(0.2 \mathrm{~g})$ was hydrolyzed with $10 \mathrm{ml}$ HCL (6N) in sealed tube, heated at $105^{\circ} \mathrm{C}$ for $12 \mathrm{hr}$.

2. The resulting solution was diluted to $25 \mathrm{ml}$ with de-ionized water.

3. After filtration, five $\mathrm{ml}$ of hydrolysate was evaporated in water bath until to be free from HCL.
4. The residue was dissolved in diluting citrate buffer (pH 2.2).

\section{Preparation of Diluting of Buffer 0.2M Na, pH 2.2}

The samples and standards were diluted with $0.2 \mathrm{ml}$ citrate buffer $\mathrm{pH} 2.2$ to proper concentration.

\section{Determination of Fatty Acids}

Fatty acids were determined according to the method described by the international Organization for Standardization (ISO 5508, 1990 and ISO, 5509, 2000).

Fatty acid methyl esters were prepared from total lipid by using rapid method according to the method of IUPAC (2000). Fatty acid methyl esters were formed by transesterification with methanolic potassium hydroxide as an intermediate stage before saponification take place.

\section{Separation and Identification of Fatty Acids Methyl Esters by Gas Liquid Chromatography (GLC)}

Fatty acid methyl esters of leaves oil were quantified by gas-liquid chromatography (HP 6890 GC capillary) equipped with a flame ionization detector (FID) using a $60 \mathrm{~m} \times 0.32$ $\mathrm{mm} \times 0.25$ um DB-23 capillary column. The injector and detector temperatures were set at $230^{\circ} \mathrm{C}$ and $250^{\circ} \mathrm{C}$, respectively. Hydrogen gas (flow rate $40 \mathrm{ml} / \mathrm{min}$.) was used as carrier gas and temperature programming was as followes: from 150 to $170^{\circ} \mathrm{C}$ at $10^{\circ} \mathrm{C} / \mathrm{min}$ and from $170^{\circ} \mathrm{C}$ to $192^{\circ} \mathrm{C}$ at $5^{\circ} \mathrm{C} / \mathrm{min}$, holding five min and from $192^{\circ} \mathrm{C}$ to $220^{\circ} \mathrm{C}$ during $10 \mathrm{~min}$. Individual methyl esters were identified by comparison to known standards.

\section{Determination of Minerals}

Acid digestion method was used to digest all the organic matter of dry moringa leaves powder with sulphuric acid for $24 \mathrm{hr}$., then digest at $125^{\circ} \mathrm{C}$. After complete digestion the samples were cooled, diluted with distilled water up to final volume of $50 \mathrm{ml}$.

Minerals were done Inactively Coupled Argon Plasma, ICAP 6500 Duo, Thermo Scientific, England, 1000 mg/l multi-element 
certified standard solution; Merk, Germany was used as stock solution for instrument standardization.

\section{Determination of Vitamins}

Determination of Vitamin C was determined according to the method of AOAC (2006).

Vitamin A and E were determined according to Noll (1996) and Pyka and Sliwiok (2001)

\section{Determination of Total Phenolic Content}

Total phenolic contents were determined by the Folin-Ciocalteu method (Siddhuraju and Becker, 2003). $0.5 \mathrm{ml}$ of moringa extract powder in distilled water (1:10) was mixed with $2.5 \mathrm{ml}$ of Folin-Ciocalteu reagent diluted in distilled water $(1: 10 \mathrm{~V} / \mathrm{V})$. The mixture was hand shaken and after $5 \mathrm{~min}$ of rest, $2 \mathrm{ml}$ of sodium carbonate $4 \%(V / V)$ were added. Samples were incubated for $2 \mathrm{hr}$., in the dark and the absorbance was measured at $740 \mathrm{~nm}$ using UV/Vis spectrometry. The calibration curve was prepared by four data points ranging from 10 to $100 \mathrm{mg} / \mathrm{l}$ solutions of gallic acid in water.

\section{Determination of Phenolic Compounds by HPLC}

Phenolic compounds were determined by HPLC according to the method of Pascale et al. (1999) as follows: $5 \mathrm{~g}$ of moringa powder sample were mixed with methanol and centrifuged at $10000 \mathrm{rpm}$ for $10 \mathrm{~min}$ and the supernatant was filtered through a $0.2 \mu \mathrm{m}$ Millipore membrane filter then $10 \mu \mathrm{l}$ was collected in a vial for injection into HPLC Agilent (series 1100) equipped with auto samplling injector, solvent degasser, UV detector set at $280 \mathrm{~nm}$ and quaternary HP pump (series 1100). The column temperature was maintained at $35^{\circ} \mathrm{C}$. Gradient separation was carried out with methanol and acetonitrile as a mobile phase at flow rate of $1 \mathrm{ml} / \mathrm{min}$. phenolic acid standard from sigma Co. were dissolved in a mobile phase and injected into HPLC. Retention time and peak area were used to calculate phenolic compounds concentration by the data analysis of Hewllet Packared software.

\section{Determination of Antioxidants Activity}

Antioxidants activity was determined by DPPH (2.2-diphenyl-1picryl hydrazyle) method according to Su and Silva (2006).

\section{Determination of Saccharides}

Sugars were determined by HPLC according to Zielinski et al. (2014) as follows: $1 \mathrm{~g}$ of sample was mixed with deionized water and centrifuged at $10000 \mathrm{rpm}$ for $10 \mathrm{~min}$ and the supernatant was filtered through a $0.2 \mu \mathrm{m}$ Millipore membrane filter then 1-3 $\mu \mathrm{l}$ was collected in a vial for injection into HPLC Agilent (series 1100) equipped with auto sampling injector, solvent degasser, IR-detector using Aminex. Carbohydrate $\mathrm{HPX}-87^{\circ} \mathrm{C}$ column $(300 \mathrm{~mm} \times 7.8 \mathrm{~mm})$. The column temperature was maintained at $85^{\circ} \mathrm{C}$. Gradient separation was carried out with deionized water and acetonitrile flow rate of $1 \mathrm{ml} / \mathrm{min}$. Sugar standard from sigma Co. was dissolved in deionized water and injected into HPLC. Retention time and peak area were used to calculate sugar compounds concentration by the data analysis of Hewllet Pack software.

\section{Statistical Analysis}

Data were analyzed by the ststistical Computer Program, SAS (2003), using the General Linear Model (GLM) procedure. All the characteristics were performed in conformity by factorial analysis and one way analysis model. The significant differences among treatments means were separated by Duncan's Multiple Range-Test (Duncan, 1955).

\section{RESULTS AND DISCUSSION}

The chemical composition of moringa leaves either fresh or dried by different drying methods was determined and the obtained results are tabulated in Table 1.

From the data presented in Table 1 it could be noticed that the moisture content of the four dehydrated samples ranged between 4.80 to $6.77 \%$ where the maximum moisture content was recorded for shadow dried sample,which was $(6.77 \%)$ while the minimum moisture content was recorded for the oven dried sample at $70^{\circ} \mathrm{C}$ which was $(4.80 \%)$. These results are consistant with the findings of Satwase et al. (2013), who found that shadow drying of moringa leaves had the highest moisture content (6.2\%) compared with sun drying, cabinet drying and oven drying at $60^{\circ} \mathrm{C}$. This could be attributed to the reduction in moisture 
Table 1. Proximate chemical composition of fresh and dried moringa leaves

\begin{tabular}{lccccc}
\hline Component (\%) & Fresh leaves & Shadow drying & \multicolumn{3}{c}{ Oven drying at } \\
\cline { 3 - 5 } & & & $\mathbf{5 0}^{\circ} \mathbf{C}$ & $\mathbf{6 0}^{\circ} \mathbf{C}$ & $\mathbf{7 0}^{\circ} \mathbf{C}$ \\
\hline Moisture & $75.42^{\mathrm{a}} \pm 0.36$ & $6.77^{\mathrm{b}} \pm 0.47$ & $5.59^{\mathrm{c}} \pm 0.13$ & $5.39^{\mathrm{c}} \pm 0.19$ & $4.80^{\mathrm{c}} \pm 0.20$ \\
Protein & $7.52^{\mathrm{c}} \pm 0.35$ & $22.90^{\mathrm{a}}+0.25$ & $22.13^{\mathrm{a}} \pm 0.20$ & $22.04^{\mathrm{ab}}+0.20$ & $21.52^{\mathrm{b}} \pm 0.32$ \\
Fat & $1.78^{\mathrm{c}} \pm 0.14$ & $9.11^{\mathrm{a}} \pm 0.13$ & $8.46^{\mathrm{b}} \pm 0.29$ & $8.04^{\mathrm{b}} \pm 0.19$ & $7.94^{\mathrm{b}} \pm 0.08$ \\
Ash & $1.90^{\mathrm{b}} \pm 0.14$ & $8.13^{\mathrm{a}} \pm 0.14$ & $7.91^{\mathrm{a}} \pm 0.14$ & $7.83^{\mathrm{a}} \pm 0.14$ & $7.71^{\mathrm{a}} \pm 0.14$ \\
Fiber & $1.99^{\mathrm{d}} \pm 0.12$ & $11.21^{\mathrm{a}} \pm 0.17$ & $10.22^{\mathrm{b}} \pm 0.19$ & $9.75^{\mathrm{c}} \pm 0.19$ & $9.36^{\mathrm{c}} \pm 0.32$ \\
Total carbohydrate & $13.38^{\mathrm{e}} \pm 0.44$ & $53.09^{\mathrm{d}} \pm 0.19$ & $55.81^{\mathrm{c}} \pm 0.19$ & $56.70^{\mathrm{b}} \pm 0.19$ & $58.03^{\mathrm{a}} \pm 0.31$ \\
\hline a,b $\ldots . .$. Means in the same row in each classification bearing different letters differ significantly $(\mathrm{P} \leq 0.05)$
\end{tabular}

content during drying that result in corresponding increase in dry matter content due to concentration of soluble solids. This is expected to improve the shelf life of the leaves since the activity of spoilage agents such as microorganisms and autolysis will be greatly hampered at such low moisture content. However, there may be an increase in the incidence of non-enzymic browning according to Derossi et al. (2011).

On the other hand, protein content of the different dehydrated samples was ranged from 21.52 to $22.90 \%$ where the shadow dried sample had the maximum protein content. These results are in agreement with those reported by Offor $e t$ al. (2014), who found that protein content of dried moringa leaves was $24.2 \%$. Madukwe et al. (2013) also found that protein content of dry moringa leaves powder was $26.28 \%$.

The present data illustrated that fat content ranged between $7.94-9.11 \%$, shadow dried samples had the highest fat content $(9.11 \%)$ while the oven dried samples at $70^{\circ} \mathrm{C}$ had the lowest fat content (7.94\%). Madukwe et al. (2013) found that the fat content of dry moringa leaves powder was $9.21 \%$.

Ash content of different dehydrated samples was in the range of 7.71 to $8.13 \%$. Ash content of shadow dried samples was the highest compared to the other dried samples. These results agree with those reported by Bussani et al. (2011) who found that ash value of dry moringa leaves powder was $7.64 \%$.
Concerning to the fiber content, results tabulated in Table 1 shows that shadow dried samples contained the highest fiber content (11.21\%), followed by oven dried samples at $50^{\circ} \mathrm{C}$ which was (10.22\%). Bussani et al. (2011) found that fiber content of dry moringa leaves powder was $11.40 \%$ and El Sohaimy et al. (2015), found that fiber content of dry moringa leaves powder was $11.23 \%$.

Carbohydrate content ranged between 53.09 to $58.03 \%$ in dried samples (Table 1), it could be observed that, the highest carbohydrate content was recorded for oven dehydrated moringa leaves at $70^{\circ} \mathrm{C}$. These results are in agreement with those reported by Madukwe et al. (2013) they found that, Carbohydrate content of dry moringa leaves powder was $49.35 \%$ and Kayi (2013) who found that, carbohydrate content of dry moringa leaves powder was $63.11 \%$, similarly Offor et al. (2014) found that carbohydrate content of dried moringa leaves from Ebonyi State, Nigeria was $50.4 \%$ and, El Sohaimy et al. (2015) found that carbohydrate content of dry moringa leaves powder was $56.33 \%$.

Data in Table 2 indicated that the leaves of moringa subjected to different dehydration methods contained 16 amino acids (8 essential amino acids and 8 non-essential amino acids). Lysin, leucine and phenylalanine were the most abundant essential amino acids in all studied samples, where their contents ranged between 36.07 to 41.65 , 5.73 to 6.74 and 4.94 to $5.50 \% \mathrm{~g} / 100 \mathrm{~g}$ protein, respectively. 
Table 2: Amino acids composition of fresh and dried moringa leaves ( $\mathrm{g} / 100 \mathrm{~g}$ protein)

\begin{tabular}{|c|c|c|c|c|c|c|c|}
\hline \multicolumn{2}{|c|}{ Amino acid } & \multirow[t]{2}{*}{ Fresh } & \multirow{2}{*}{$\begin{array}{l}\text { Shadow } \\
\text { drying }\end{array}$} & \multicolumn{3}{|c|}{ Oven drying } & \multirow{2}{*}{$\begin{array}{l}\text { Egg amino } \\
\text { acids reference }\end{array}$} \\
\hline & & & & $50^{\circ} \mathrm{C}$ & $60^{\circ} \mathrm{C}$ & $70^{\circ} \mathrm{C}$ & \\
\hline \multicolumn{8}{|c|}{ Essential } \\
\hline 1 & Phenylanaline & 5.02 & 5.44 & 4.94 & 5.50 & 5.40 & 5.70 \\
\hline 2 & Threonine & 1.92 & 1.99 & 2.00 & 2.20 & 1.88 & 5.10 \\
\hline 3 & Methionine & 0.32 & 0.37 & 0.79 & 0.56 & 0.56 & 3.40 \\
\hline 4 & Leucine & 5.73 & 6.36 & 6.17 & 6.74 & 6.46 & 8.80 \\
\hline 5 & Isoleucine & 2.39 & 2.76 & 2.51 & 2.87 & 2.89 & 6.30 \\
\hline 6 & Lysine & 41.65 & 37.23 & 40.61 & 36.32 & 36.07 & 7.00 \\
\hline 7 & Valine & 4.10 & 4.62 & 4.25 & 4.83 & 5.78 & 6.80 \\
\hline 8 & Histidine & 3.35 & 3.70 & 3.36 & 3.78 & 3.88 & - \\
\hline & Total & 64.48 & 62.47 & 64.63 & 62.80 & 62.92 & 43.1 \\
\hline \multicolumn{8}{|c|}{ Non-essential } \\
\hline 9 & Aspartic & 8.37 & 8.02 & 6.57 & 6.81 & 7.27 & \\
\hline 10 & Serine & 2.34 & 2.46 & 2.18 & 2.37 & 2.34 & \\
\hline 11 & Glutamic & 10.41 & 10.91 & 10.10 & 11.16 & 11.07 & \\
\hline 12 & Proline & 0.05 & 0.10 & 0.07 & 0.10 & 0.10 & \\
\hline 13 & Glycine & 6.59 & 7.07 & 7.73 & 7.62 & 7.40 & \\
\hline 14 & Tyrosine & 1.46 & 1.63 & 2.14 & 1.70 & 1.45 & \\
\hline 15 & Cystine & - & - & - & - & - & \\
\hline \multirow[t]{2}{*}{16} & Alanine & 6.29 & 7.33 & 6.58 & 7.45 & 7.46 & \\
\hline & Total & 35.51 & 37.52 & 35.37 & 37.21 & 37.08 & \\
\hline
\end{tabular}

These findings are in accordance with those reported by El-Masry et al. (2013), who found that the major essential amino acids of moringa leaves were leucine, phenylalanine and lysine.

Glutamic, aspartic acid and alanine were the major non-essential amino acids, of all studied samples ranging between 10.10 to $11.16,6.57$ to $8.37 \%$ and 6.29 to $7.46 \mathrm{~g} / 100 \mathrm{~g}$ protein, respectively. Cystine was not detected in all studied samples of moringa leaves. Bussani et al. (2011) found that moringa leaves had a very low content of cystine $(0.01 \%)$.

Results in Table 2 illustrate obviously that all studied samples of moringa leaves had low contents of essential amino acid compared to egg protein, with one exception related to lysine, which was higher than that of egg by 5 folds approximately.

The variations in the amino acid composition could be influenced by protein quality and the origin of the plant (cultivated or wild). Usually cultivated plants are fertilized which could influence the quality of proteins (Sanchez-Machado et al., 2009).

The Fatty acids composition of moringa leaves either fresh or dried by different drying methods are shown in Table 3. 
Seventeen fatty acids were identified in dried moringa leaves. Data presented in Table 3 demonstrated that $\mathrm{C}_{8: 0}$ and $\mathrm{C}_{10: 0}$ were not detected in all studied samples. The major saturated fatty acid in all studied samples of moringa leaves was palmitic acid $\left(\mathrm{C}_{16: 0}\right)$, which ranged between 4.95 and $10.77 \%$. The lowest concentration was found in oven dried moringa leaves at $70^{\circ} \mathrm{C}$. Sample dried in shadow and dried sample in oven at $50^{\circ} \mathrm{C}$ had highest concentration of palmitic acid which were $9.89 \%$ and $10.77 \%$, respectively. The major unsaturated fatty acid was $\alpha$-Linolenic $\mathrm{C}_{18: 3 n 3}$ being $31.11 \%$ for sample dried in oven at $50^{\circ} \mathrm{C}$ and $52.46 \%$ for sample dried in oven at $60^{\circ} \mathrm{C}$. Total saturated fatty acids content ranged between $8.69 \%$ for oven sample dried at $70^{\circ} \mathrm{C}$ and $24.53 \%$ for sample dried in shadow at ambient temprature. On the other hand, the total unsaturated fatty acids content ranged between $49.77 \%$ for oven dried sample at $50^{\circ} \mathrm{C}$ and $66.70 \%$ for oven dried samples at $60^{\circ} \mathrm{C}$. There are very important two ratios; the first is saturated /unsaturated ratio which related to oil stability, while the second is oleic/linoleic which related to palatability.

From the previous results, it could be concluded that the higher of drying temperature, the lowers of the oil stability. The highest palatability was recorded for the fresh sample while the lowest palatability was recorded for the oven dried sample at $70^{\circ} \mathrm{C}$.

Fatty acids profiles obtained in the present study come in partial agreement with results obtained by Compaoré et al. (2011). SanchezMachado et al. (2009) reported that $\alpha$-linolenic acid had a higher value of $56.87 \%$ of interest was $\alpha$-linolenic, which is an n-3 fatty acid that belongs to the group of the essential fatty acids.

Findings differ in the present study from that of Sanchez-Machado et al. (2009) who found 14 fatty acids, which could be attributed to the age of the leaves, soil type and climatic conditions.

The minerals content of different samples of moringa leaves either in the fresh or with dried are shown in Table 4.

Calcium, potassium, magnesium, and iron are the major minerals detected in all studied samples. The highest value of calcium and iron were in shadow drying sample and drying at $70^{\circ} \mathrm{C}$ being 2208 and $2036 \mathrm{mg} / 100 \mathrm{~g}$, respectively. The highest contents of potassium and magnesium were found when dried in oven treatment at $70^{\circ} \mathrm{C}$, being 1000 and $398.2 \mathrm{mg} /$ 100g; respectively; Selenium was not detected in all studied samples. These results are in agreement with those reported by El-Masry et al. (2013) and Yameogo et al. (2011), they found that the major elements in dried moringa oleifera leaves were calcium, potassium and magnesium.

Cadmium, cobalt, chromium, molybdenum, lead and vanadium were detected in minor concentrations. These results are in agreement with data reported by Severino et al. (2009), who stated that cadmium, arsenic, chromium and lead were lower or not detected in some samples of moringa leaves collected from different areas .

Differences observed between the obtained results and those reported in literature can be attributed to geographical, soil composition, cultivation climate, ripening stage varity of moringa and harvesting time of leaves and the extraction method used (Compaoré et al., 2011).

\section{Vitamins Content of Fresh ad Dried Moringa Leaves}

Vitamins play an important role in improving human health promoting. Vitamin A is a natural antioxidant capable of inhibiting free radicals formation and is important for improving the immune system. Vitamin $\mathrm{E}$ is useful for enhancing the immune system function and skin repair. Vitamin C is very important for cardiovascular health and reducing free radicals in the cells (Thurber and Fahey, 2009).

The content of vitamins $\mathrm{A}, \mathrm{E}$ and $\mathrm{C}$ of moringa leaves either in the fresh or in the dried by different drying techniques were determined and the obtained results are demonstrated in Figs. 1, 2 and 3.

The content of vitamin A was $15.71 \mathrm{mg} /$ $100 \mathrm{~g}$ in moringa leaves dried at $70^{\circ} \mathrm{C}$, compared with the fresh moringa leaves which was 33.07mg/100g (Fig. 1). 
Table 3. Fatty acid composition of fresh and dried moringa leaves (g/100g fat)

\begin{tabular}{|c|c|c|c|c|c|c|}
\hline \multirow[t]{2}{*}{ Fatty acid } & & \multirow[t]{2}{*}{ Fresh } & \multirow{2}{*}{$\begin{array}{c}\text { Shadow } \\
\text { drying }\end{array}$} & \multicolumn{3}{|c|}{ Oven drying at } \\
\hline & & & & $50^{\circ} \mathrm{C}$ & $60^{\circ} \mathrm{C}$ & $70^{\circ} \mathrm{C}$ \\
\hline Lauric & $\mathrm{C}_{12: 0}$ & 0.40 & 0.36 & 0.38 & N.D & N.D \\
\hline Myritic & $\mathrm{C}_{14: 0}$ & 0.59 & 1.31 & 1.17 & 0.52 & 0.47 \\
\hline Tetradecenoic & $\mathrm{C}_{14: 1}$ & N.D & 0.99 & 0.46 & 0.17 & N.D \\
\hline Pentadecanoic & $\mathrm{C}_{15: 0}$ & 0.07 & 0.13 & 0.19 & 0.13 & N.D \\
\hline Pentadecanoic (cis-10) & $\mathrm{C}_{15: 1}$ & 0.28 & 0.09 & 0.26 & 0.76 & 1.09 \\
\hline Palmitic & $\mathrm{C}_{16: 0}$ & 8.02 & 9.89 & 10.77 & 7.52 & 4.95 \\
\hline Palmitoleic & $\mathrm{C}_{16: 1}$ & 1.67 & 4.31 & 3.21 & 0.29 & 0.24 \\
\hline Margaric & $C_{17: 0}$ & 0.24 & 0.31 & 0.39 & 0.33 & 0.36 \\
\hline Heptadecnoic(cis-10) & $\mathrm{C}_{17: 1}$ & 0.04 & 0.05 & 0.09 & 0.12 & N.D \\
\hline Stearic & $\mathrm{C}_{18: 0}$ & 1.94 & 1.40 & 1.57 & 1.63 & 1.47 \\
\hline Oleic & $\mathrm{C}_{18: 1}$ & 4.19 & 2.97 & 3.07 & 2.73 & 2.37 \\
\hline Linoleic & $\mathrm{C}_{18: 2}$ & 6.59 & 9.05 & 9.27 & 6.45 & 7.77 \\
\hline g-Linolenic & $\mathrm{C}_{18: 3 \mathrm{n} 6}$ & 1.31 & 1.79 & 1.19 & 1.73 & 1.53 \\
\hline$\alpha$-Linolenic & $\mathrm{C}_{18: 3 \mathrm{n} 3}$ & 40.22 & 32.01 & 31.11 & 52.46 & 42.61 \\
\hline Arachidic & $\mathrm{C}_{20: 0}$ & 5.37 & 10.02 & 4.39 & 0.63 & 0.18 \\
\hline gondoic & $\mathrm{C}_{20: 1}$ & 1.44 & 1.00 & 1.11 & 1.69 & 0.73 \\
\hline Behenic & $\mathrm{C}_{22: 0}$ & 1.45 & 1.47 & 1.44 & 1.10 & 1.26 \\
\hline \multicolumn{2}{|l|}{ Total unknown } & 26.14 & 22.82 & 29.89 & 21.70 & 34.96 \\
\hline \multicolumn{2}{|c|}{ Total saturated fatty acids } & 17.68 & 24.53 & 19.92 & 11.86 & 8.69 \\
\hline \multicolumn{2}{|c|}{ Total unsaturated fatty acids } & 55.74 & 52.26 & 49.77 & 66.70 & 56.34 \\
\hline \multicolumn{2}{|c|}{ Totalsaturated/total unsaturated } & 0.31 & 0.46 & 0.40 & 0.17 & 0.15 \\
\hline \multicolumn{2}{|l|}{ Oleic / lenoleic } & 0.63 & 0.32 & 0.33 & 0.42 & 0.30 \\
\hline
\end{tabular}


Table 4. Mineral content in fresh and dried moringa leaves ( $\mathrm{mg} / \mathbf{1 0 0 g})$

\begin{tabular}{lccccc}
\hline Mineral & Fresh & Shadow drying & \multicolumn{3}{c}{ Oven drying } \\
\cline { 3 - 6 } & & & $\mathbf{5 0}{ }^{\circ} \mathbf{C}$ & $\mathbf{6 0}^{\circ} \mathbf{C}$ & $\mathbf{7 0}^{\circ} \mathbf{C}$ \\
\hline Calcium & \multicolumn{5}{c}{ Major mineral } \\
Magnesium & 1805 & 19698 & 220 & 1974 & 2036 \\
Potassium & 328.8 & 378 & 352.2 & 368.2 & 398.2 \\
& 720 & 840 & 820 & 860 & 1000 \\
Aluminum & & Trace mineral & & & \\
Boron & 27.8 & 44,38 & 33.78 & 38.04 & 33.6 \\
Cadmium & 9.858 & 10.204 & 9.552 & 13.668 & 13.716 \\
Cobalt & 0.01 & 0.01 & 0.01 & 0.01 & 0.01 \\
Chromium & 0.03 & 0.03 & 0.044 & 0.032 & 0.032 \\
Copper & 0.2 & 0.2 & 0.2 & 0.2 & 0.2 \\
Iron & 0.632 & 0.72 & 0.764 & 0.844 & 0.892 \\
Manganese & 41.14 & 60.32 & 48.24 & 47.72 & 48.28 \\
Molybdenum & 6.448 & 7.656 & 6.44 & 7.338 & 8.022 \\
Nickel & 0.02 & 0.02 & 0.02 & 0.02 & 0.02 \\
Lead & 0.188 & 0.17 & 0.19 & 0.138 & 0.164 \\
Vanadium & 0.086 & 0.11 & 0.188 & 1.2 & 0.82 \\
Selenium & 0.22 & 0.362 & 0.132 & 0.1 & 0.12 \\
Zinc & $\mathrm{N} . \mathrm{D}$ & $\mathrm{ND}$ & $\mathrm{N} . \mathrm{D}$ & $\mathrm{N} . \mathrm{D}$. & $\mathrm{N} . \mathrm{D}$ \\
& 2.524 & 2.864 & 2.576 & 2.614 & 3.05 \\
\hline & & & & \\
\hline
\end{tabular}

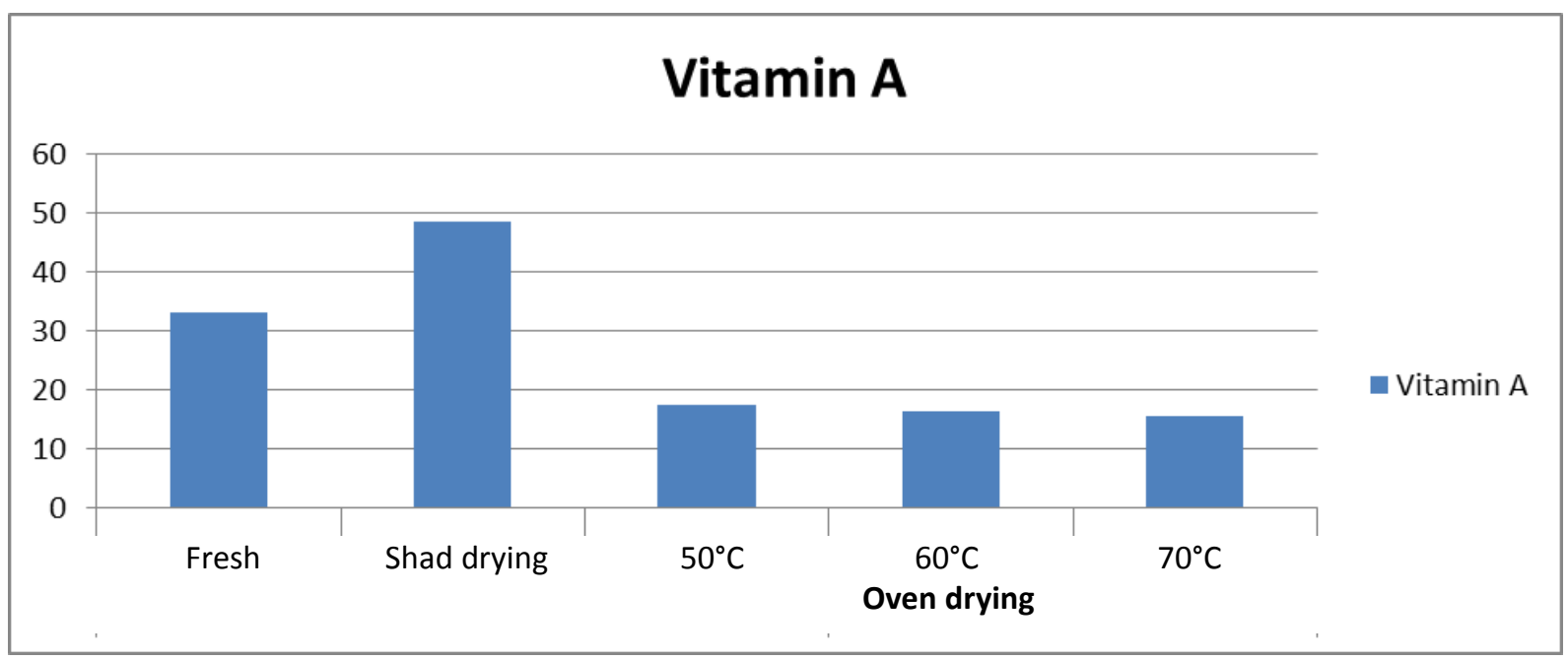

Fig. 1. Vitamin A content of fresh, shadow and oven dried moringa leaves 


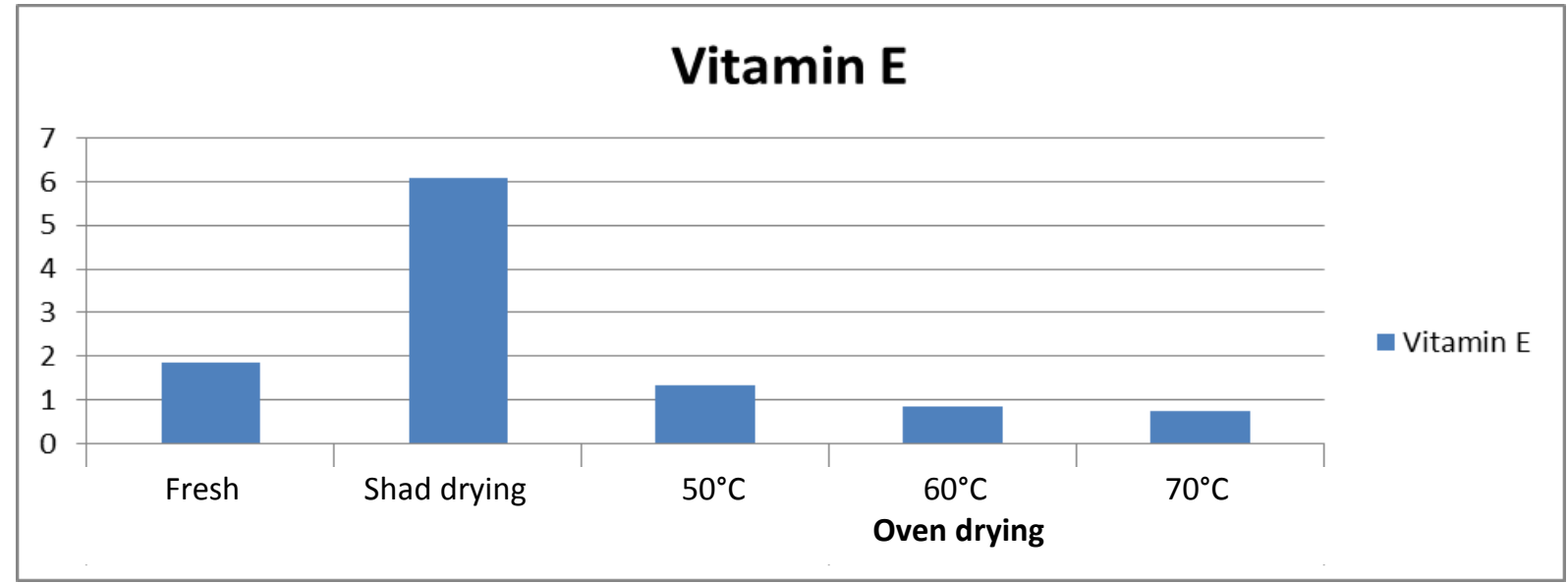

Fig. 2. Vitamin E content of fresh, shadow and oven dried moringa leaves

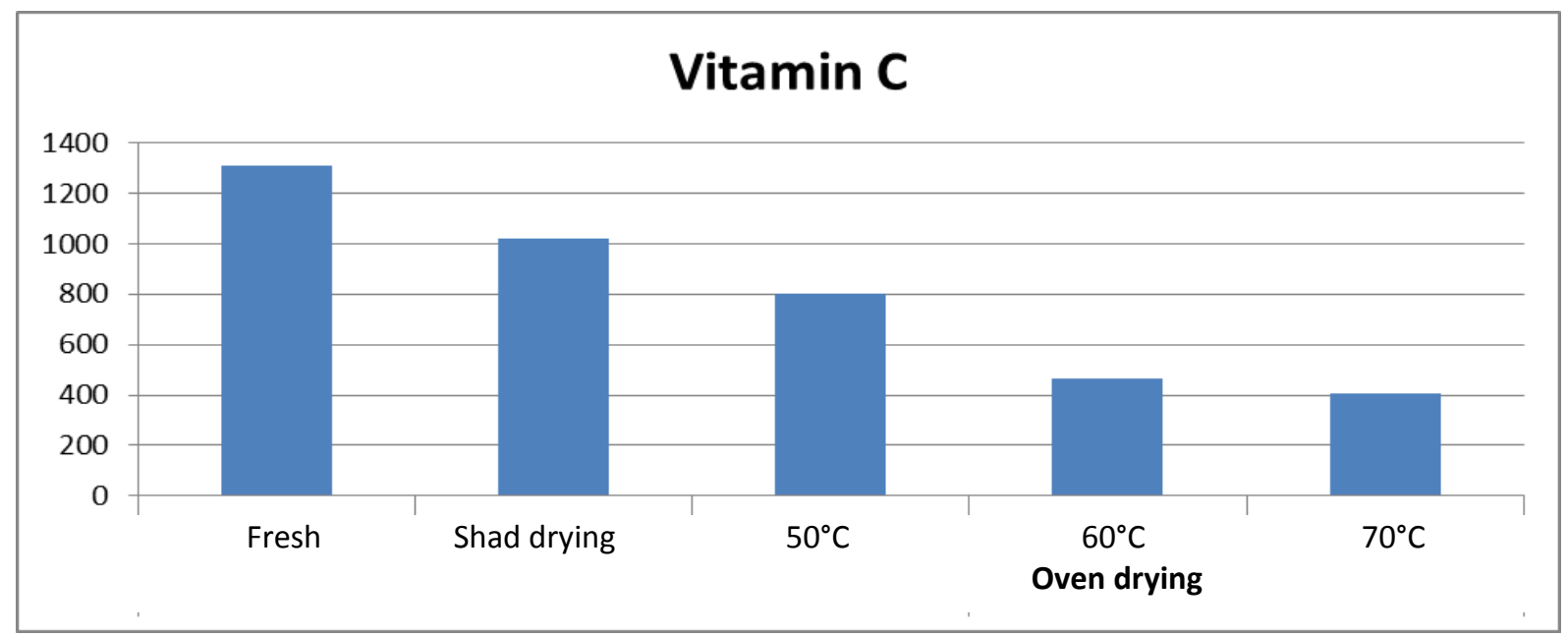

Fig. 3. Vitamin C content of fresh, shadow and oven dried moringa leaves

The content of vitamin $\mathrm{E}$ was $0.73 \mathrm{mg} /$ $100 \mathrm{~g}$ in moringa leaves dried at $70^{\circ} \mathrm{C}$, compared with the fresh moringa leaves which was $1.84 \mathrm{mg} / 100 \mathrm{~g}$ (Fig. 2). Similarly vitamin C content was $407.3 \mathrm{mg} / 100 \mathrm{~g}$ in moringa leaves oven dried at $70^{\circ} \mathrm{C}$ compared with the fresh moringa leaves which was $1312 \mathrm{mg} / 100$ g (Fig. 3)

Data in Figs. 1, 2 and 3 shows that different drying temperatures led to decrease vitamins $\mathrm{A}$, $\mathrm{E}$ and $\mathrm{C}$ contents. Moringa leaves dried in shadow were characterized by the highest vitamin content compared to oven dried samples.

These results are in agreement with those reported by Olabode et al. (2015), who found that ascorbic acid and ß-carotene (pro vitamin A) were decreased as a result of raising drying temperature from 60 to $80^{\circ} \mathrm{C}$.

Mbah et al. (2012) found that shadow drying had the highest content of vitamin A compared to either fresh, or oven dried samples of moringa leaves.

\section{Total Polyphenol Content of Fresh and Dried Moringa Leaves}

Phenolic compounds and flavonoids are very important constituents due to antioxidant activity. The moringa leaves might be regarded as a promising rich source of phenolic compounds. Polyphenols content of fresh and dried moringa leaves are shown in Fig. 4. 


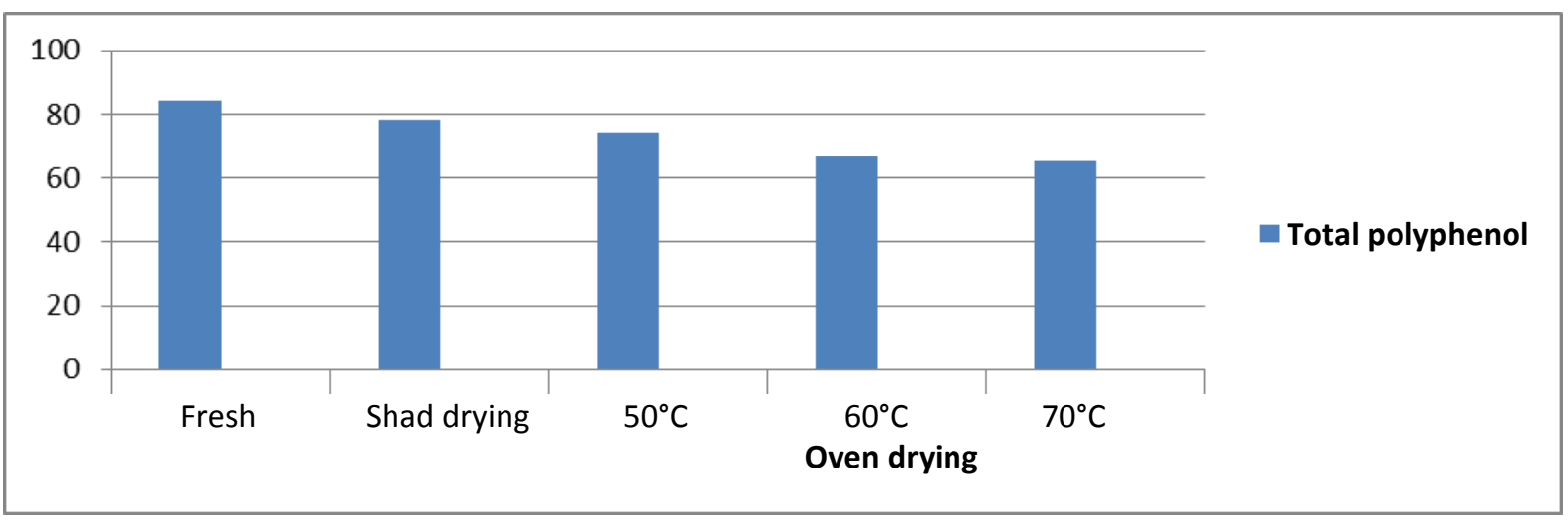

Fig. 4. Total Polyphenol content of fresh and dried moringa leaves (expressed as $\mathbf{m g} / \mathbf{1 0 0 g}$ sample)

The highest total polyphenol content was recorded in fresh samples (84.2 $\mathrm{mg} / 100 \mathrm{~g})$ followed by shadow dried samples which was (78.00). The lowest total polyphenol content was recorded for the oven dried samples at $70^{\circ} \mathrm{C}$ (65.5 mg/100g).

These results are in agreement with those reported by Singh and Prasad (2013), they found that the total polyphenol content of moringa leaves ranged from 23.57 to $155.15 \mathrm{mg} / 100 \mathrm{~g}$ depending on the drying temperature, particle size and blanching process. El-Masry et al. (2013) reported that total polyphenol contents were reduced as a result of drying process in comparison with fresh samples.

Based in the presented data of amino acids, fatty acids, vitamins, and minerals, it can be included that the drying of fresh moringa leaves, using shadow drying was found to be the best method, thus, shadow dried moringa leaves powder was subjected to analysis of phenolic compounds composition, antioxidant activity, and sugar composition.

Twenty three phenolic compounds were identified in shadow dried moringa leaves. The major phenolic compounds were e-vanillic (893.99 ppm), alpha-coumaric (518.85 ppm), pyrogallol (172.72 ppm), and salycilic acid (171.11 ppm), while the lowest contents were, ellagic (5.81 ppm), 3-OH-tyrosol (8.25 ppm), cinnamic (9.75 ppm), reversetrol (118.84 ppm) and iso-ferulic (11.62 ppm).

These results disagree with those reported by El-Masry et al. (2013) they found that, the major phenolic compounds in moringa leaves were rutin, caffeic acid, ferulic acid and quercetin, while the minor phenolic compounds were kampferol, syringic acid and ellagic acid.

The antioxidants activity was observed in dried moringa leaves powder being 92.46\%.

Twelve sugars were identified in shadow dried sample of moringa leaves by HPLC analysis. The detected sugars were in the form of neutral such as stachyose (1009.75 mg/100g), raffinose (607.89 $\mathrm{mg} / 100 \mathrm{~g})$, sucrose (608.68 $\mathrm{mg} / 100 \mathrm{~g})$, lactose167.49 $\mathrm{mg} / 100 \mathrm{~g})$, xylose (314.76 mg/100g), galactose (102.45 mg/100g), mannose (221.55 mg/100g) and ribose(12.28 $\mathrm{mg} / 100 \mathrm{~g}$ ), acidic sugars such as glucouronic (876.59 mg/100g) and galactouronic (164.33 $\mathrm{mg} / 100 \mathrm{~g}$ ) as well as alcoholic sugar such as manitol and sorbitol were detected in shadow dried moringa leaves powder (Table 6). The higest sugar concentration was stachyose being $1009.75 \mathrm{mg} / 100 \mathrm{~g}$ followed by glucuronic (876.59), sucrose (608.88 $\mathrm{mg} / 100 \mathrm{~g})$ and raffinose $(607.89 \mathrm{mg} / 100 \mathrm{~g})$

On the other hand ribose, sorbitol and manitol were present in low concentration, being $12.28,18.25$ and $35.63 \mathrm{mg} / 100 \mathrm{~g}$, respectively. Moderate concentration of xylose, mannose, lactose, and galacturonic (314.76, 221.55, 167.49 and $164.33 \mathrm{mg} / 100 \mathrm{~g}$, respectively, were also detected. Leone et al. (2015) analyzed sugars of Moringa oleifera leaves in chad, Sahrawi refugee camps, and Haiti. Sugar content was very different among the samples. Sucrose content was higher in the leaves collected in the Sahrawi camps, $7.96 \mathrm{~g} / 100 \mathrm{~g}$ while the leaves collected in Haiti were the richest in glucose and fructose $4.57,4.81 \mathrm{~g} / 100 \mathrm{~g}$, respectively. 
Table 5. Phenolic compounds of shadow dried on moringa leaves

\begin{tabular}{lc}
\hline Phenolic compound & Concentration of phenolic compound(ppm) \\
\hline Gallic & 10.86 \\
Pyrogallol & 172.72 \\
4-Amino-benzoic & 42.58 \\
3-oH-Tyrosol & 8.25 \\
Protocatchuic & 41.27 \\
Chlorogenic & 126.87 \\
Catechein & 126.12 \\
Catechol & 39.13 \\
Caffeine & 18.39 \\
P-OH-benzoic & 144.46 \\
Caffeic & 65.04 \\
Vanillic & 90.21 \\
p-coumaric & 34.22 \\
Ferulic & 18.08 \\
ISO-ferulic & 11.62 \\
Reversetrol & 118.84 \\
Ellagic & 5.81 \\
e-vanillic & 893.99 \\
Alpha-coumaric & 518.85 \\
3,4,5 methoxy-cinnamic & 21.48 \\
Coumarin & 13.86 \\
Salycilic & 171.11 \\
Cinnamic & 9.75 \\
\hline
\end{tabular}

Table 6. Sugars composition of shadow dried moringa leaves powder

\begin{tabular}{lc}
\hline Sugar & Concentrate (mg /100g) \\
\hline Stachyose & 1009.75 \\
Raffinose & 607.89 \\
Sucrose & 608.68 \\
Xylose & 314.76 \\
Galactose & 102.45 \\
Mannose & 221.55 \\
Manitol & 35.63 \\
Sorbitol & 18.25 \\
Ribose & 12.28 \\
Glucuronic & 876.59 \\
Galacturonic & 164.33 \\
\hline
\end{tabular}




\section{Conclusion}

From the previous results,it can be concluded that the shadow drying method was the best method for drying moringa leaves. It characterized by high retention of nutrients like protein, fats as well as crude fiber, minerals compared to drying by oven. The abundantly available inexpensive leaves of moringa can serve as a rich source of nutrients and can be used in the developing countries to combat malnutrition.

\section{REFERENCES}

Anhwange, B.A., V.O. Ajibola and S.J. Oniye (2004). Chemical studies of the seeds of Moringa oleifera (Lam.) and Detarium microcarpum (Guill and Sperr). J. Biol. Sci., (4): 711-715.

Anwar F.; M. Ashraf and M.I. Bhanger (2005). Interprovenance variation in the composition of Moringa oleifera oil seeds from Pak. J. Am. Oil Chem. Soc., (82):45-51.

Anwar, F.; S. Latif; M. Ashraf and A. H. Gilani (2007). Moringa oleifera: A food plant with multiple medicinal uses, Phytotherapy Research, (21): 17-25.

AOAC (2005). Offical Methods of Analysis, Association of Official Analytical Chemists. Food Compositition, additives natural contaminants. Adrich RC (ed.) (2) $15^{\text {th }}$ Ed. Association of Official Analytical Chemist Inc. USA.

AOAC (2006). Official Methods of Analysis of AOAC International $18^{\text {th }}$ Ed. Am. Oil Chem. Soc. Press: Champaign, IL.

Aremu, A.K. and A. Akintola (2014). Effects of some drying methods on nutritional characteristics of moringa (Moringa oleifera) seeds. IPCBEE, 75.

Bussani, M., J.M. Patrick, H. Arnold and M. Voster (2011). Nutritional characterization of Moringa (Moringa oleifera L.) leaves. Afri. J. Biotechnol., 10 (60): 12925 - 12933.

Caceres, A., A. Saravia, S. Rizzo, L. Zabala, E. Deleon and F. Nave (1992). Pharmacologic properties of Moringa oleifera. 2: Screening for antispasmodic, antiinflammatory and diuretic activity. J. Ethnopharmacol., (36): 233-237.

Compaore, W.R., P.A. Nikiema, H.I.N. Bassole, A. Savadego, J. Mouecoucou, D.J. Hounhouigan and S.A. Traore (2011). Chemical composition and antioxidative properties of seeds of Moringa oleifera and pulps of Parkia biglobosa and Adansonia digitata commonly used in food fortification in Burkina Faso. Current Res. J. Biol. Sci., 3 (1): $64-72$.

Csomos, E. and L. Simon-Sarkadi (2002). Characterisation of tokaj wines based on free amino acids and biogenic amines using ionexchange chromatography. Chromatographia Supp., 56:185-188.

Dangi, S.Y.J., C.I. olly and S. Narayana (2002). Antihypertensive activity of the total alkaloids from the leaves of Moringa oleifera. J. Pharmac. Biol., 2 (40): 144-148.

Derossi, A., C. Severini and D. Cassi (2011). Mass transfer mechanisms during dehydration of vegetable food: Traditional and Innovative Approaches. In: El-Amin, M. (Ed). Advanced Topics in Mass Transfer. Croatia, in Tech., 305- 54.

Duncan, D.B. (1955). Multiple Range and Multiple F tests. Biometrics, 11 :1-42.

El Sohaimy, S.A., G.M. Hamad, S.E. Mohamed, M.H. Amar and R.R. Al-Hindi (2015). Biochemical and functional properties of Moringa oleifera leaves and their potential as a functional food. J. Agric. Sci., 4 (4) 188199.

El-Masry, F.H.M., M.E.M. Mossa and S.M. Youssef (2013). Moringa oleifera plant "Value and utilization in Food processing. Egypt. J. Agric. Res., 91 (4) : 1597-1609.

Fahey, J.W. (2005). Moringa oleifera: A Review of the medical evidence for its nutritional, therapeutic, and prophylactic properties. Part 1.Trees for Life J., 1: 1-33.

Folkard, A. and H.O. Sutherland (1996).The Moringa oleifera plant supplement of the board trade J. Bulletin of the Imperial Inst., 45-107. 
ISO 5508 (1990).Animal and vegetable fats and oils - Analysis by gas chromatography of methyl esters of fatty acids. Int. St.

ISO 5509 (2000).Animal and vegetable fats and oils- Preparation of methyl esters of fatty acids. Int. St.

IUPAC (2000). Standard Methods for the Analysis of Oils, Fats and Derivatives, $7^{\text {th }}$ Ed., Pub. Int. Union of Pure and Appl. Chem., Oxford, Great Britain.

Kayi, K. (2013). A study on Moringa oleifera leaves as a supplement to West African weaning foods. http://www.haw-hamburg. de/ hibs.html.

Khalafalla, M.M., E. Abdellatef, H.M. Dafalla, A.A. Nassrallah, K.M. Aboul-Enein, D.A. Lightfoot, F.E. El-Deeb and H.A. El-Shemy (2010). Active principle from Moringa oleifera Lam leaves effective against two leukemias and a hepatocarcinoma. Afr. J. Biotechnol., 9 (49): 8467-8471.

Leone, A., G. Fiorillo, F. Criscuoli, S. Ravasenghi, L. Santagostini, G. Fico, A. Spadafranca, A. Battezzati, A. Schiraldi, F. Pozzi, S. di Lello, S. Filippini and S. Bertoli (2015). Nutritional characterization and phenolic profiling of Moringa oleifera leaves grown in Chad, Sahrawi Refugee Camps, and Haiti. Int. J. Mol. Sci., 16: 18923-18937.

Liman, M.G., A.S. Abdullahi, A.L. Maigoro and K.J. Umar (2014). Effects of three drying techniques on mineral composition of some leafy garden vegetables. Appl. Chem., 7: 3842.

Madukwe, E.U., A.L. Ugwuoke and J.O. Ezeugwu (2013). Effectiveness of dry Moringa oleifera leaf powder in treatment of anaemia. Int. J. Med. and Med. Sci., 5(5) 226-228.

Mbah, B.O., P.E. Eme and A.E. Paul (2012). Effect of drying techniques on the proximate and other nutrient composition of Moringa oleifera leaves from two areas in Eastern Nigeria. Pak. J. Nut., 11 (11): 1044-1048

Mukunzi, D., J. Nsor-Atindana, Z. Xiaoming, A. Gahungu, E. Karangwa and G. Mukamurezi (2011). Comparison of volatile profile of
Moringa oleifera leaves from Rwanda and China using HS-SPME. Pak. J. Nut., 10: 602-608.

Nambiar, V. and M. Daniel (2005). Polyphenol content of three Indian green leafy vegetables. J. Food Sci. and Technol., 42 (6): $312-315$

Noll, G.N. (1996). High-performance liquid chromatographic analysis of retinal and retinol isomers. J. Chrom. A, 721: 247-259.

Offor, I.F., R.C. Ehiri and C.N. Njoku (2014). Proximate nutritional analysis and heavy metal composition of dried Moringa oleifera leaves from Oshiri Onicha L.G.A, Ebonyi State, Nigeria. ISSN (8) 2319-2399.

Olabode, Z., C.T. Akanbi, B. Olunlade and A. A. Adeola (2015). Effects of drying temperature on the nutrients of Moringa (Moringa oleifera) leaves and sensory attributes of dried leaves infusion. J. Agric. and Food Sci., 3 (5): 117-122.

Pascale, G., H. Mireille, B. Patrick and J.A. Marie (1999). Effect of enzymatic treatment on polyphenolics content in prickly pear (Opuntia ficus indica) juice. J. Sci. Food and Agric., 79: 1625-1634.

Price, M.L. (2007). The moringa tree. Echo Technical Note. Florida, USA, 1-12.

Pyka, A. and J. Sliwiok (2001). Chromatographic separation of tocopherols. J. Chrom. A, 935: 71-76.

Sanchez-Machado, D.I., J.A. Nunez-Gastelum, C. Reyes-Moreno, B. Ramirez-Wong, J. Lopenz-Cervantes (2009). Nutritional quality of edible parts of Moringa oleifera. Food Anal Method. DOI 10.1007/s1261- 0099106-Z.

SAS (2003). Statistical Analysis System Institute Inc. Users Guide, Version 9, USA.

Satwase, A.N., G.R Pandhre, P.G. Sirsat and Y.R. Wade (2013). Studies on drying characteristic and nutritional composition of drumstick leaves by using sun, shadow, cabinet and oven drying methods. Open Access Sci. Rep., 2(1): 1-4. 
Severino, S.M., M. Cecilia, M. Raquepo and C.D. Pabustan (2009). Mineral macronutrients, micro-nutrients and other elements in leaves of malunggay plant (Moringa Oleifera) sampled in some locations in the Philippines. Pca-Canfarms Technol. Adv. Notes, 3 (5): 117-122

Siddhuraju, P. and K. Becker (2003). Antioxidant properties of various solvent extracts of total phenolic constituents from three different agro-climatic origins of drumstick tree (Moringa oleifera Lam.). J. Agric. Food Chem., 15: 2144-2155.

Singh, Y. and K. Prasad (2013). Moringa oleifera leaf as functional food powder: characterization and uses. Inter. J. Agric. and Food Sci. Technol. ISSN 2249-3050, 4 (4) : 317-324.

Su, M. and J.L. Silva (2006). Antioxidant activity, anthocyanins, and phenolics of rabbit eye blueberry (Vaccinium ashei) by- products as affected by fermentation. Food Chem., 97:.447-451.

Thurber, M.D. and J.W. Fahey (2009). Adoption of Moringa oleifera to combat undernutrition viewed through the lens of the "Diffusion of Innovations" theory. Ecol. Food Nut., 48 (3): 212 - 225.

Yameogo, C.W., D.B. Marcel, S. Aly, A.N. Philippe and S.A. Traore (2011). Determination of chemical composition and nutritional values of Moringa oleifera leaves. Pak. J. Nut., 10 (3) : 264 - 268.

Zielinski, A.A., B. Cintiamaia, I.M. Demiate, F.L. Beltrame, A. Nogueira and G. Woslacki (2014). Development and Optimization on a HPLC-RI method for determination of major sugars in apple juice and evaluation of the effect of the ripening stage. Food Sci. Technol,. Campinas, 34 (1): 38-43. 


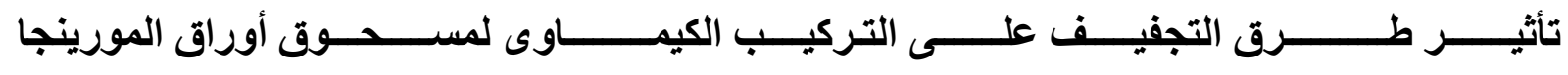

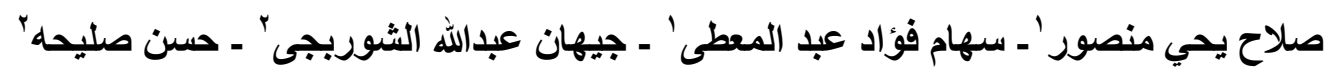

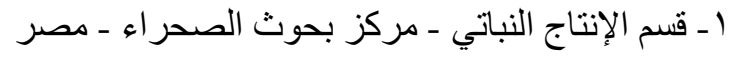

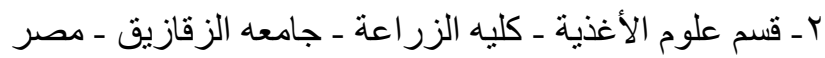

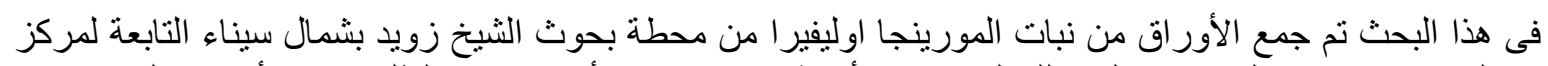

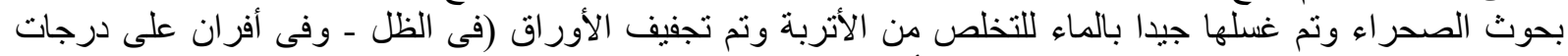

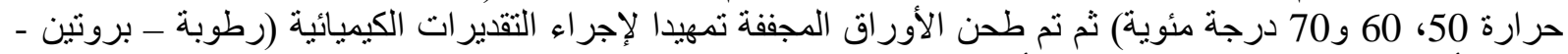

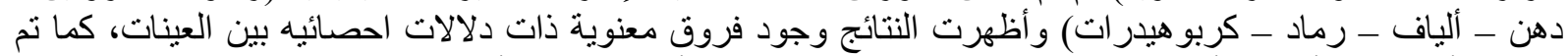

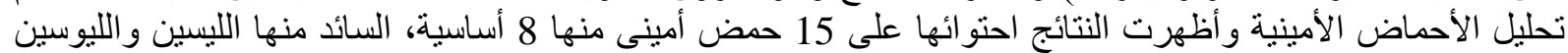

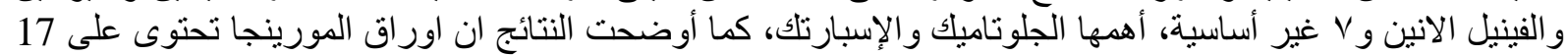

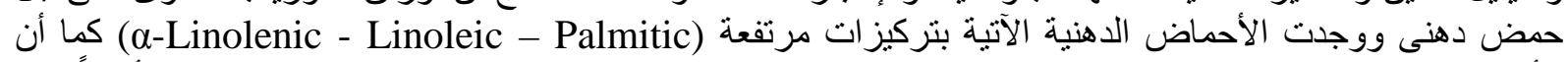

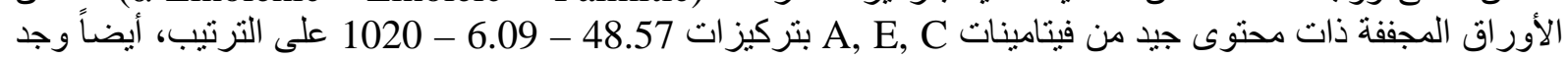

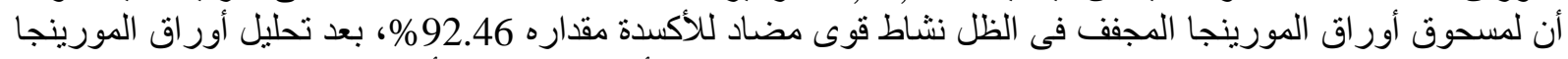

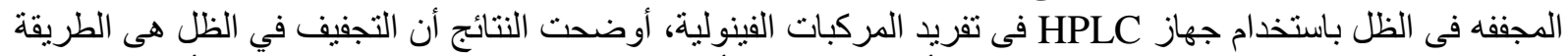

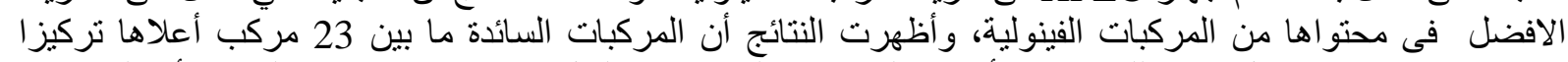
(e-vanillic

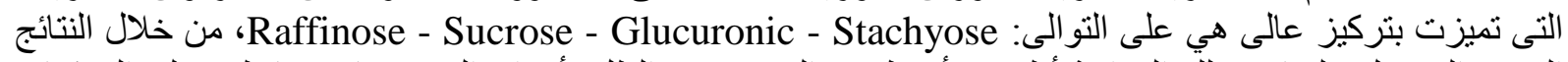

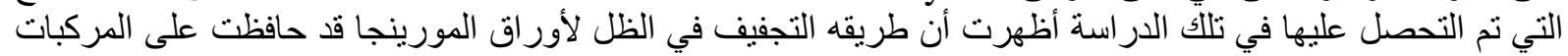
الفعالة بصوره ملحوظة مقارنة بالتجفيف على درجات الحرار التهرة المختلفة بالفرن الكهربائي. 